\title{
Study on the Groundwater Accumulation of Oke-Ogba Area using Groundmagnetic Survey
}

\author{
1*ALAGBE, OA; ${ }^{2}$ SUNMONU, L A; ${ }^{3}$ ADABANIJA, M A \\ ${ }^{I}$ Departmement of Physics and Solar Energy, Bowen University, Iwo -Nigeria \\ ${ }^{2}$ Department of Pure and Applied Physics, Ladoke Akintola University of Technology, Ogbomoso-Nigeria \\ ${ }^{3}$ Department of Earth Sciences, Ladoke Akintola University of Technology, Ogbomoso-Nigeria.
}

\begin{abstract}
A ground magnetic survey of Oke-Ogba area in Akure part of south western Nigeria was carried out with the aim of establishing dominant hydrogeologic factors responsible for groundwater development of the area. A total of four transverses were established for the groundmagnetic survey, and the results were presented as groundmagnetic profiles of varying magnetic intensities. The basement topography was obtained from the profiles using half-width method. The interpretation of magnetic intensities of the profiles revealed a network of geological features such as faults, joints and fractures. The high magnetic intensity at the central portion of the constructed magnetic contour map indicates shallow basement. This was corroborated with quantitatively interpreted result which established overburden thickness to the top of the magnetic basement rock as varied between 3.0 and $21.0 \mathrm{~m}$. Groundmagnetic study of Oke-Ogba area has revealed the efficacy of magnetic prospecting technique as a fast reconnaissance tool for identifying geological features and estimation of basement depth. The study has established geological features as more prominent hydrogeologic indicator for groundwater development in the area. @ JASEM
\end{abstract}

The purpose of magnetic survey is to locate rocks or minerals having unusual magnetic properties which reveal themselves as anomalies in the intensity of the earth's magnetic field (Abdelrahman and Essa, 2005). It has been used extensively in basement mapping (Folami 1992). In the present study, magnetic method has been used to delineate subsurface linear geologic structures which may be related to groundwater accumulation in Oke-Ogba area of Akure, south-west Nigeria.

\section{MATERIALS AND METHODS}

The instrument used for the groundmagnetic survey is the Geometries proton precession magnetometer, model G-856. The magnetometer utilized the precession of spinning protons in the sample of fluid Decane to measure the total magnetic dipoles and they are temporarily aligned in a uniform magnetic field generated by a current in coil of wire wound around the sample (Decane).

When the current is automatically cut off the proton precesses about the direction of the earth's magnetic field. The preceding protons generate a small signal in the same coil used in polarizing them. The frequency of the signal is proportional to the total magnetic field intensity and independent of the orientation of the sensor in the magnetometer (Keary and Brooks 1991,Telford et al. 1990). If the spin angular momentum of the proton is $\mathrm{L}$, and its magnetic moment $\mu$ the angular velocity $w$ of the precession in a field $\mathrm{T}$, is given as:

$$
w=\left(\frac{\mu}{L}\right) T \quad \ldots .1
$$

Where $\mu$ is the magnetic moment and $\frac{\mu}{L}$ is the gyromagnetic ratio. The angular velocity $\mathrm{w}$ is related to frequency $F$ through the expression $w=2 \pi F$ .....2

Therefore, inserting this expression in equation (1) yields

$$
\begin{aligned}
& 2 \pi F=\left(\frac{\mu}{L}\right) T \\
& \text { Or } \quad \ldots .33 \\
& T=2 \pi\left(\frac{\mu}{L}\right) F \quad \ldots . .4
\end{aligned}
$$

The working relation from equation (4) is given by (Gardland, 1971) as: $T=23.4874 F \quad \ldots .5$

Where $\mathrm{T}$ is in gammas and $\mathrm{f}$ is the measured frequency in hertz.

This proton magnetometer produces an absolute and relatively high resolution of the field and displays measurement in digital lighted readout. A total of four transverses were established for the groundmagnetic survey, and the results were presented as groundmagnetic profiles of varying magnetic intensities. 


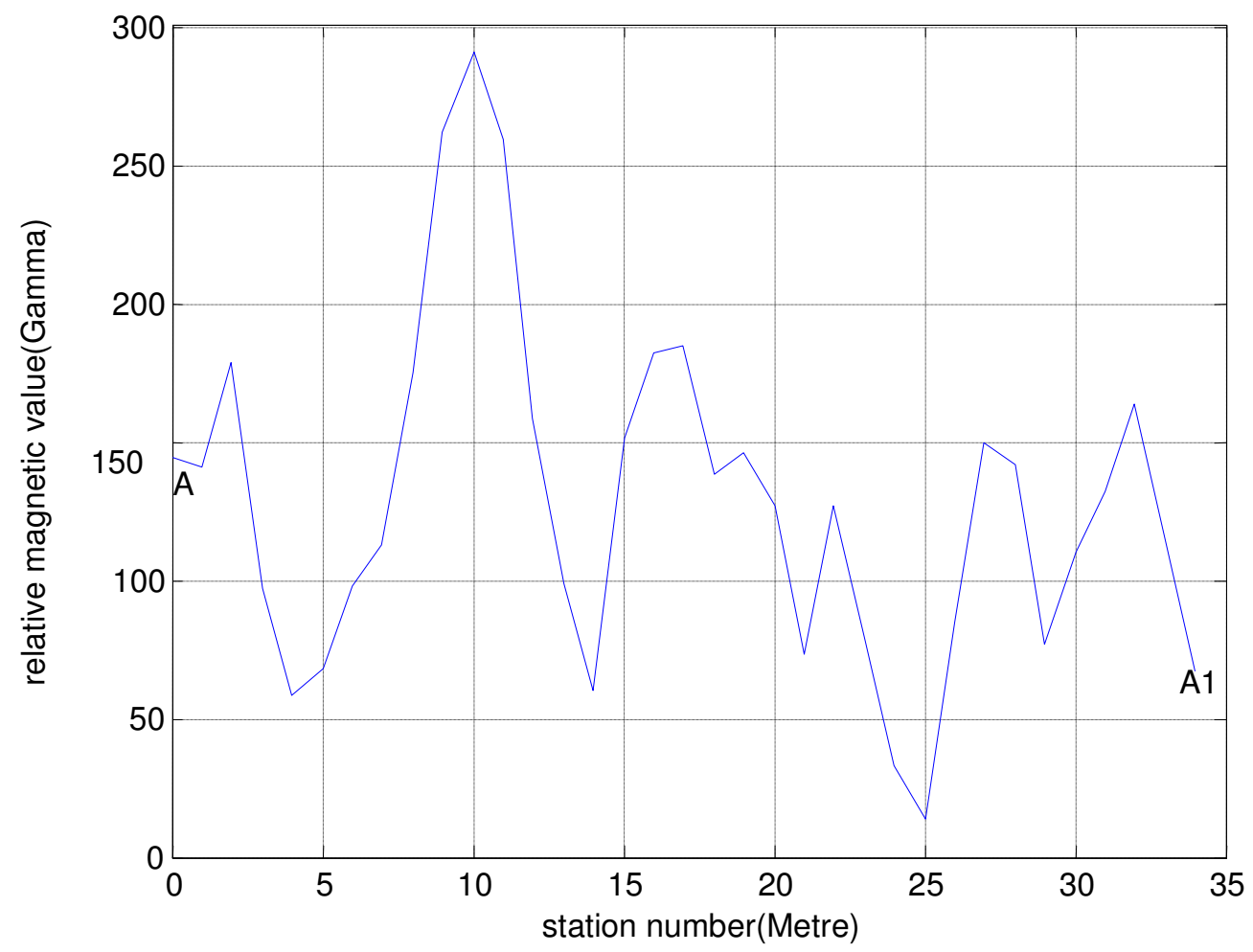

Fig. 1; $\mathrm{AA}_{1}=$ Anomaly distance along profile 1

The instrument however gives magnetic intensity values in gamma and was used for ground magnetic prospecting of Oke-Ogba area along four (4) profiles in North-South and East-West directions. The profiles lengths range between 180 and $350 \mathrm{~m}$ with inter profile spacing of about 30 to $90 \mathrm{~m}$ and station separation of $10 \mathrm{~m}$. The magnetic readings were corrected for non-mean, near surface effect, and drift correction. The noises were removed by filtering the data using three-point moving average filter (Breiner, 1973). The eventual magnetic data were presented as profiles by plotting the relative magnetic values against station separations for each profile. Magnetic contour map was also constructed for a more qualitative interpretation. The quantitative interpretation involved the use of half-width method for the estimation of overburden thickness (Folami, 1992). The estimated magnetic depths to the basement along each profile were determined and presented in Table 1 as AA1 to DD1 for profiles 1 to 4, while probable geologic structures causing the anomalies along each profile were also given in Table 2 based on the estimated depth to basement.
The Study Area: Oke-Ogba area is located on longitude $5^{0} 6^{\prime}$ to $5^{0} 12^{\prime}$ E latitude $7^{0} 14^{\prime}$ to $7^{0} 19^{\prime}$. It is situated at the Southern part of Akure township and on a rugged and gentle undulating terrain characterized by outcrop of granite and charnokite rocks. The climate of the area comprises short dry season and long wet season. The wet season last from April to November with a peak in Jume and July. These are vindicated by dense evergreen forest vegetation. The dry season last from November to March with December and January being the driest months . The temperature varies between $25^{\circ} \mathrm{C}$ and $30^{\circ}$ throughout the year with high humility during the wet season and low humidity during the dry season (Iloeje 1972,1980). Oke-Ogba falls within the southwestern portion of Nigeria basement complex which lie within the pan African mobile belt, east of West African craton. The basement complex is believed to be polycyclic (Rahaman, M.A. 1976). Locally the study area is underlain by basement rock types such as slightly migmatite gneiss complex rocks that are slightly migmatised to non-migmatite metasedimentary and meta-igneous rocks, charnockites and granite rocks. These rocks occur as 
iceberg, isolated and continuous hills. Low lying outlying outcrops of magmatite gneiss and quartzite boulders were also seen in the survey site. The topsoil ranges from sandy clay to dark loamy soil and gravel aggregates.

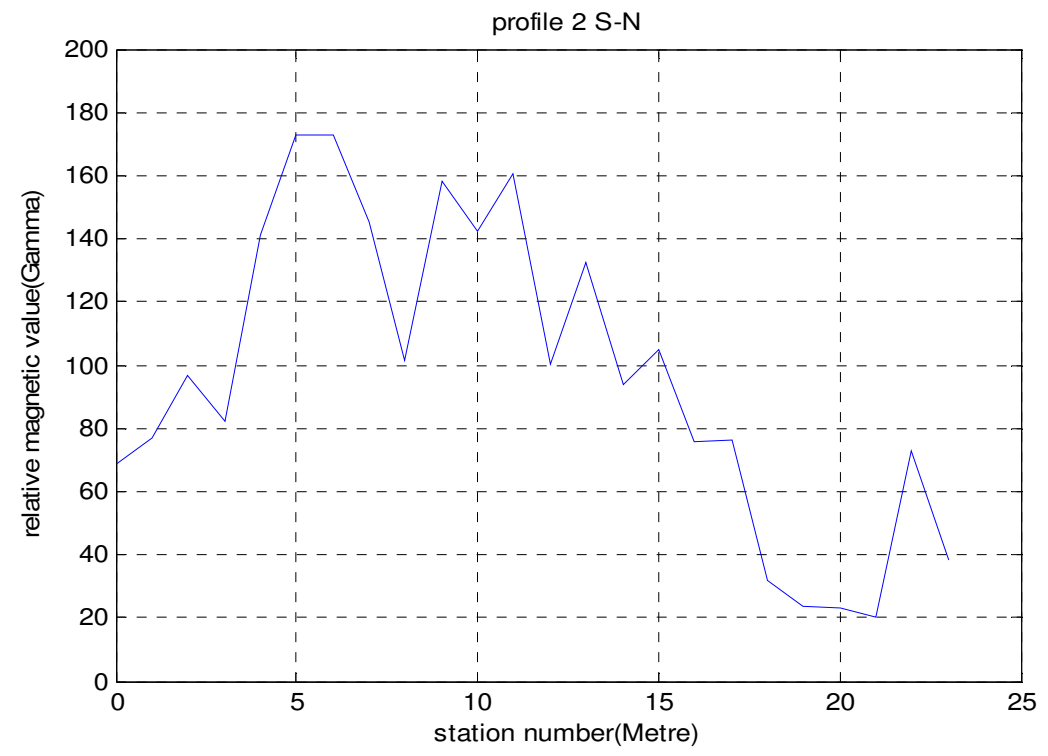

Fig. 2; $\mathrm{BB}_{1}=$ Anomaly distance along profile 2

\section{RESULTS AND DISCUSSION}

The results of the groundwater magnetic survey of the Oke-Ogba area were discussed in terms of quantitative and qualitative interpretations. The quantitative interpretation involves the estimation of the overburden thickness to the top of the magnetic basement, and is as shown in Table 1. It indicated varied basement topography with depth ranging from 3.0 to $21.0 \mathrm{~m}$. The depth range agrees with the result obtained by Adelusi (2002), 2.3 - 21.2m using electrical resistivity method.

Table 1: Depth Estimates of Groundmagnetic Profiles Relative to the Ground Surface from Oke-Ogba Area Using Half-Width Method

\begin{tabular}{|l|l|l|l|l|l|l|l|l|}
\hline $\begin{array}{l}\text { Profile } \\
\text { Numbe } \\
\text { r }\end{array}$ & $\begin{array}{l}\text { Profil } \\
\text { e Line }\end{array}$ & \multicolumn{7}{|l|}{} \\
\hline & & 1 & 2 & 3 & 4 & 5 & 6 & 7 \\
\hline 1 & AA1 & 4.0 & $\begin{array}{l}15 . \\
0\end{array}$ & $\begin{array}{l}9 . \\
0\end{array}$ & $\begin{array}{l}4 . \\
0\end{array}$ & 6. & 8.0 & $\begin{array}{l}16 . \\
0\end{array}$ \\
\hline 2. & BB1 & 7.0 & 21. & 4. & 4. & 6. & 5.0 & 5.0 \\
& & & 0 & 0 & 0 & 0 & & \\
\hline 3. & CC1 & 16. & 5.0 & 4. & 6. & 5. & & \\
& & 0 & & 0 & 0 & 0 & & \\
\hline 4. & DD1 & 4.0 & 3.0 & 5. & 6. & 6. & 12. & \\
& & & & 0 & 0 & 0 & 0 & \\
\hline
\end{tabular}

(AA1, BB1, CC1 and DD1 are anomaly lengths along the profiles)
The qualitative interpretation involves interpretation of the magnetic profiles and magnetic contoured map

Magnetic Profiles: Profile 1: The profile covers a total length of 350 metres AA1 (figure 1) and trends in a west-east direction. The profile generally shows low magnetic values which is an indicative of a fault or fracture. Profile 2: The profile covers a total length of 250 metres along BB1 (figue 2) and trends in a South-North direction. The profile generally shows high magnetic values which correspond to the location of undifferentiated basement rock which may includes schist and granite gneiss. The stations interval between 190 metres and 210 metres however shows a low magnetic value and so an indicative of a fault or fracture. Profile 3: The profile is in a NorthSouth direction and a lateral extent of $230 \mathrm{~m}$ along CC1(figure 3). The station positions 30, 70, 130, and 170 meters shows low magnetic values while all other stations along the profile have high magnetic values. The low magnetic values are indicative of a fault or fracture while the high magnetic values are indicative of an undifferentiated basement rock. Profile 4: This as shown in Figure 4 and it is along DD1. All sampling points along the profile show high magnetic values except at distance $48 \mathrm{~m}$ which has low magnetic value indicating probably a vein. The summary of quantitative and qualitative interpretations of the profile is as shown in Table 2. 


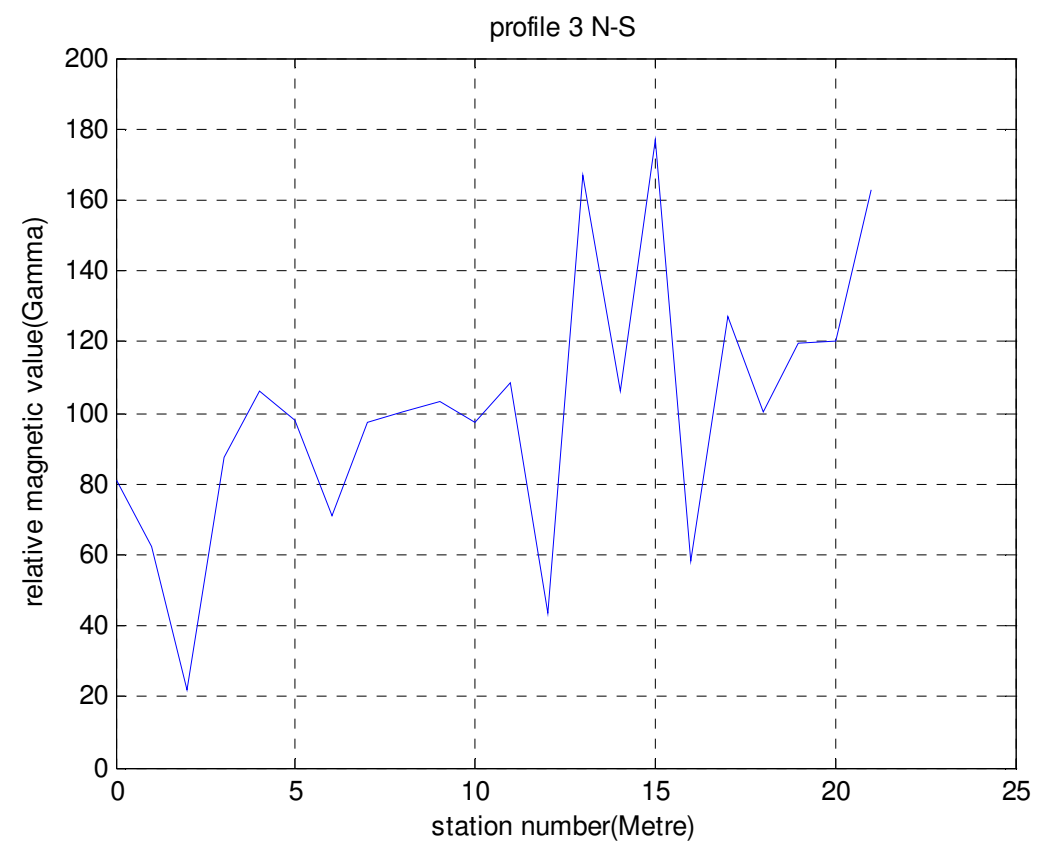

Fig. 3; $\mathrm{CC}_{1}=$ Anomaly distance along profile 3

Magnetic Contour Map: The magnetic contour map constructed using the magnetic values for the study area is as shown in (figure 5). The magnetic values increases outward from central portion with a NESW dip at 100gamma contour value. This indicates geological features such as joints faults fractures or rock contact. Higher magnetic values above 200gammas characterized the northeastern and southeastern portion of the study area indicating undifferentiated basement rock. However, high magnetic intensity at the central portion of the contour map indicates shallow overburden.

Table 2: Summary of Quantitative and Qualitative Interpretation of the Profile

\begin{tabular}{|c|l|l|}
\hline PROFILES & $\begin{array}{l}\text { Estimate of depth to } \\
\text { basement range }\end{array}$ & Geological structures \\
\hline $1 \quad\left(\mathrm{AA}_{1}\right)$ & $4.0-16.0 \mathrm{~m}$ & Fault or Fracture \\
\hline $2\left(\mathrm{BB}_{1}\right)$ & $4.0-21.0 \mathrm{~m}$ & Undifferentiated Basement rock, Fault or Fracture \\
\hline $3\left(\mathrm{CC}_{1}\right)$ & $4.0-16-0 \mathrm{~m}$ & Undifferentiated Basement rock, Vein \\
\hline $4\left(\mathrm{DD}_{1}\right)$ & $3.0-12.0 \mathrm{~m}$ & Vein, Undifferentiated Basement rock \\
\hline
\end{tabular}

(AA1, BB1, CC1 and DD1 are anomaly lengths along the profiles)

Hydrogeologic Appraisal: Basement rocks are known to have very low porosity and negligible permeability. The development of aquifers is therefore limited to the overburden resulting from the in-situ chemical weathering of the bedrock and fissure/fracture systems in the underlying bedrock. In the study area, the depth to basement is relatively shallow 3.0 to $21.0 \mathrm{~m}$. This should not be considered as disadvantageous as the thickness of the weathered layer has been a controversial factor in hydrogeologic appraisal (Adabanija e tal 2008). In some literature, Benson and Jones (1988), and Chilton and Foster
(1995), for instance, the consensus is that boreholes should be sited where the regolith is thickest. Whereas in some literature, the thickness need not be great to have a good yield of water e.g. Briz-kishore and Bhiman Sankaram (1982); Venkafeswara Rao and Briz-kishore (1991), but must be deep enough for water to be safe for consumption e.g. Wright (1990). However, there are some prominent geological features in the area favourable for groundwater extraction. These include veins, fracture and or faults. Therefore from Table 2, only some sampling points along profile AA1, BB1 because of their relatively 
thick overburden and geological structures; and to some extent along profile CC1 and DD1 are suitable

for groundwater development in the area.

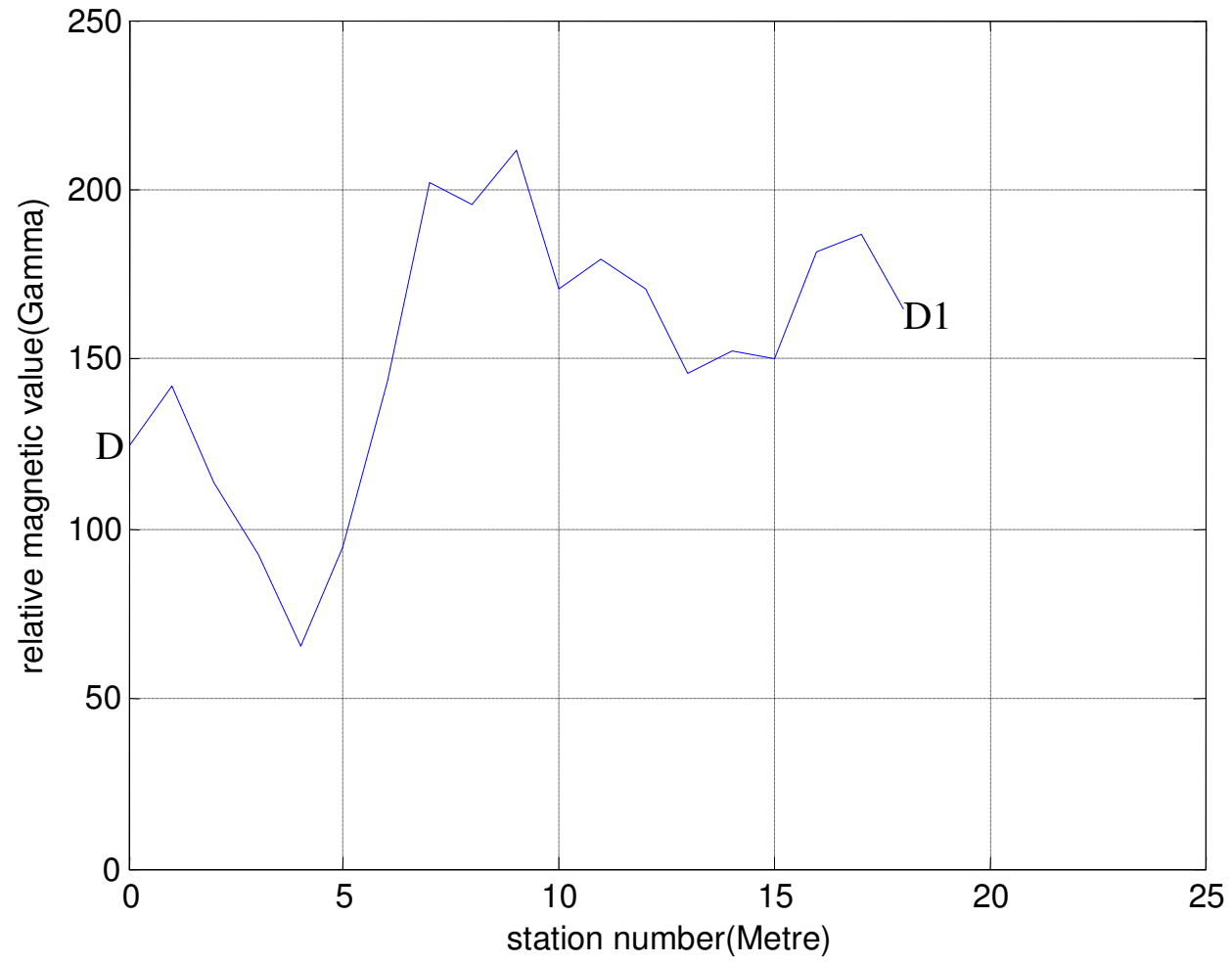

Fig. 4; $\mathrm{DD}_{1}=$ Anomaly distance along profile 4

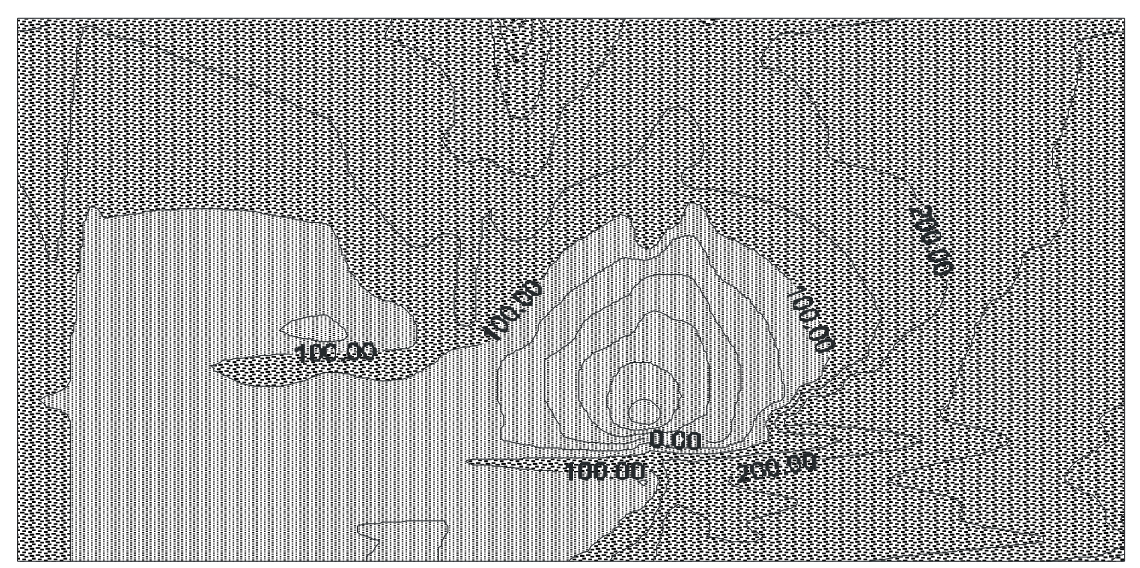

FIGURE 5: MAGNETIC CONTOURED MAP OF OKE-OGBA, AKURE.

The groundmagnetic study of Oke-Ogba area in Akure parts of Southwestern Nigeria basement complex has been investigated. The study revealed a network of geologic features along some of the profiles and undifferentiated basement rock at some other locations. The estimated depth to top of magnetic basement range of $3.0 \mathrm{~m}$ to $21.0 \mathrm{~m}$ agrees with the value previously established for the study area using electrical resistivity method. Magnetic prospecting technique has therefore proved to be a versatile and fast reconnaissance tool for delineating geological features and estimation of basement depths in the study area. The study has also shown that geological features rather than overburden thickness have more dominant hydrogeologic indicators for groundwater development in the area. 


\section{REFERENCES}

Abdelrahman, E M.; Essa, K S. (2005). Magnetic interpretation using a least-squares depth-shape curves method. Geophysics 70 ( 3) L23 -L30.

Adabanija, M.A; Omidiora, E.O; Olayinka, A.I, (2008). Fuzzy logic modeling of the resistivity sounding measurement and topography features for aquifer assessment in hydrogeological investigation of basement complex. Hyrogeol. Journal $16 ; 461-481$

Benson, S. and Jones, C.R.C. (1988). The combined EMT geophysical method for sitting boreholes. Groundwater 26 ; 45-63

Breiner, S (1973). Applications Manual for portable Magnetometer.Geometrics. California;46-47

Briz-Kishore, B H ; Bhiman San Karam, V L S (1982). Analysis and evaluation of groundwater potentialities in the granitic acquifer system of Shadnargar Basin. Geophysics Res. Bull 20 ( 3) 173-181.

Folami, S L (1992) Interpretation of Aeromagnetic Anomalies in Iwaraja Area. southwestern Nigeria. Journal of Minning and Geology 28 ( 2) 391-396

Iloeje, N P (1972, 1980). A New Geography for West Africa. Longman Group Limited ;3-33.
Keary, P; Brooks M (1991). An introduction to geophysical exploration, Second Edition: Blackwell scientific publications, London ; 156157

Rahaman, M A (1976). Review of Basement Geology of Southwestern Nigeria. Geology of Nigeria ;158.

Salem, A Ravat D; Smith R; Ushijima K (2005). Interpretation of magnetic data using an enhanced local wavenumber (ELW) method. Geophysics 70 ( 2 ) L7-L12.

Telford, W M; Geldart, L P; Sheriff (1990). Applied Geophysics. Second Edition Cambridge University Press;133-135

Venkateswara Rao, B ; Briz-Kishore, B H (1990). Influence of topography over the yield of borewells in a typical Khondalitic formation. In: Proc. Semin. On groundwater resources development and management in Andhra Pradesh(India), state groundwater dept. govt. of Andhra Pradesh, 43-50

Wright, E P (1990). Basement aquifers in Africa: Commonwealth Science Council Technical Paper 273 ( II ) 363-394.

Wright, E P ; Burgress, W G (1992). The hydrogeology of crystalline basement aquifer in Africa. Geological society special publication 66 ; 203-220 